\title{
Chemical, microbiological and sensory evaluation of mayonnaise prepared from ostrich eggs
}

\author{
By Ferial M. Abu-Salem and Azza A. Abou -Arab
}

\author{
Department of Food Technology, National Research Centre, Dokki, Cairo, Egypt \\ E-mail: ferial_mas@yahoo.com
}

\section{RESUMEN}

Evaluación química, microbiológica y sensorial de mayonesa preparada con huevos de avestruz.

En este trabajo se ha evaluado la composición química y el contenido mineral de los huevos de avestruz. Asimismo se ha realizado la evaluación química, microbiológica y sensorial de la mayonesa preparada con huevos de avestruz en comparación con la preparada con huevos de gallina. Los resultados han mostrado que los huevos de avestruz son una buena fuente de proteínas $(47,09 \%)$, lípidos totales $(45,10 \%)$ carbohidratos $(4,03 \%)$, calcio $(206,5 \mathrm{mg} / 100 \mathrm{~g})$, fósforo $(683,8$ $\mathrm{mg} / 100 \mathrm{~g})$, potasio $(460 \mathrm{mg} / 100 \mathrm{~g})$, sodio $(408,7 \mathrm{mg} / 100 \mathrm{~g})$ y zinc $(5,2 \mathrm{mg} / 100 \mathrm{~g})$. La evaluación química de la mayonesa pasteurizada y no pasteurizada indicó que la mayonesa preparada con huevos de avestruz era más resistente al deterioro químico debido a autoxidación que la preparada con huevos de gallina. La mayonesa de huevos de avestruz almacenada sin pasteurizar fue asociada con una acidez valorable significativamente mayor $(P<0,05)$. Por el contrario, la acidez valorable no se alteró en las muestras pasteurizadas. Sin embargo, en la mayonesa de huevos de gallina la acidez valorable no varió ni en las muestras pasteurizadas ni en las no pasteurizadas. El grado de acidez y el valor del ácido tiobarbitúrico de las mayonesas de huevos de avestruz y de huevos de gallina pasteurizadas y no pasteurizadas aumentaron significativamente $(P<0,01)$ con el periodo de almacenamiento, estos aumentos fueron significativamente $(P<$ $0,05)$ menores en mayonesa pasteurizada en comparación con la no pasteurizada tanto en el caso de huevos de avestruz como de gallina. La evaluación microbiológica mostró que la mayonesa de huevos de avestruz era estable y resistente al deterioro microbiano durante el almacenamiento debido a una disminución en los valores de $\mathrm{pH}$. Las puntuaciones obtenidas en la evaluación sensorial para el sabor, flavor, color, apariencia y aceptabilidad global fueron significativamente $(P<0,05)$ más altas para la mayonesa de huevos de avestruz que para la de huevos de gallina.

PALABRAS CLAVE: Evaluación sensorial - Huevos de avestruz - Mayonesa.

\section{SUMMARY}

Chemical, microbiological and sensory evaluation of mayonnaise prepared from Ostrich eggs.

Ostrich eggs were evaluated for their chemical composition and mineral contents. Also, chemical, microbiological and sensory evaluation of the mayonnaise made from ostrich eggs in comparison to that made from chicken eggs were studied. Data indicated that ostrich eggs are a good source of protein $(47.09 \%)$, total lipids $(45.10 \%)$, carbohydrates $(4.03 \%)$, calcium $(206.5 \mathrm{mg} / 100 \mathrm{~g})$, phosphorus (683.8 mg/100g), potassium (460 $\mathrm{mg} / 100 \mathrm{~g})$, sodium $(408.7$ $\mathrm{mg} / 100 \mathrm{~g})$ and zinc $(5.2 \mathrm{mg} / 100 \mathrm{~g})$. The chemical evaluation of unpasteurized and pasteurized mayonnaise indicated that mayonnaise made from ostrich eggs was more resistant to chemical spoilage due to auto-oxidation than that made from chicken eggs. In ostrich egg mayonnaise, stored unpasteurized was associated with significantly $(P<0.05)$ greater titratable acidity (T.A). Conversely, T.A did not alter in stored pasteurized samples. However, in chicken egg mayonnaise T.A was not affected in pasteurized or unpasteurized samples. The acid value (AV) and thiobarbituric acid (TBA) number of unpasteurized and pasteurized mayonnaise made from ostrich or chicken eggs were significantly $(P<0.01)$ increased as storage period increased. These increases in AV and TBA values were significantly $(P<0.05)$ decreased in pasteurized mayonnaise in comparison to the unpasteurized one made from either ostrich or chicken eggs. Microbiological evaluation proved that ostrich egg mayonnaise was stable and resistant to microbial spoilage during storage which was due to a decrease in $\mathrm{pH}$ values. Sensory evaluation scores of taste, flavor, color, appearance and overall acceptability were significantly $(P<0.05)$ higher for ostrich egg mayonnaise than for chicken egg mayonnaise. luations.

KEY-WORDS: Mayonnaise - Ostrich eggs - Sensory eva-

\section{INTRODUCTION}

Eggs have been called «nature's perfect food». This is because they are one of the few complete protein foods, i.e. they contain all the nine essential amino acids which cannot be manufactured from the body but must be obtained from foods (Agriculture and Agri. Food Canada, 1999).

Eggs are considered one of the most important foodstuffs and probably one of the first multifunctional food ingredients. They are wellknown for their whipping, gelling and emulsification properties (Davis and Reeves, 2002). Eggs play an important role in food preparation. The three most recognized uses for eggs are: liquid egg will coagulate or solidify when heated (to produce cakes, etc.); aeration (whipping) creates lighter and airier products (e.g. merengue); and emulsification of egg yolk phospholipids and lipoproteins will produce salad dressings and sauces (Stadelman, 1999).

Mayonnaise is probably one of the most widely used sauces or condiments in the world today. It was first produced commercially in the early 1900s, 
and became popular in America from 1917 to 1927 (Harrison and Cunningham, 1985) and more recently in Japan where sales increased by $21 \%$ a year from 1987 to 1990 (Brabant, 1992). Because of its low $\mathrm{pH}$ and high fat content, mayonnaise is relatively resistant to microbial spoilage. Mayonnaise is an oil-in-water emulsion and is traditionally prepared from a mixture of egg yolk, vinegar, oil and spices (especially mustard); it may also include salt, sugar or sweeteners, and other optional ingredients (Depree and Savage, 2001). Pasteurization causes little or no damage to the functional properties and does not affect the formation of stable mayonnaise (Palmer et al., 1969).

The aim of this investigation was to study the chemical composition of ostrich and chicken eggs and to evaluate the chemical, microbiological, sensory properties and storage conditions of mayonnaise prepared from ostrich eggs compared to mayonnaise from chicken eggs.

\section{MATERIALS AND METHODS}

\subsection{Materials}

The ingredients used in this investigation were corn oil, white vinegar ( $6 \% \mathrm{w} / \mathrm{v}$ acetic acid), salt and mustard purchased from a local supermarket. However, fresh chicken eggs were purchased from a local grocery store and ostrich eggs from the Egyptian company of ostrich breeding, Cairo, Egypt. The egg yolk was separated from the whites and the yolk was rolled onto a filter paper to remove adhering egg white fragments (Aluko and Mine, 1997). After puncturing of the yolk membrane, the liquid yolk was collected in a clean beaker and used in mayonnaise preparation.

\subsection{Mayonnaise preparation}

Mayonnaise was prepared from ostrich and chicken eggs using the following formula: fresh egg yolk $(15 \%)$, white vinegar $(12 \%)$, corn oil $(70 \%)$, salt $(2 \%)$ and dry mustard $(1 \%)$. The mixing of ingredients was performed using an electric mixer (Braun Combimax 700, Type 3202). The dry ingredients were mixed separately in a container using one-third of the total amount of vinegar until a smooth paste was obtained. The paste was added to the egg yolk and mixed for $5 \mathrm{~min}$. Oil was added slowly under continuous mixing to form the emulsion; after all the oil had been added, mixing continued for $5 \mathrm{~min}$. This was followed by the addition of the remaining vinegar and mixing continued for additional $5 \mathrm{~min}$ (Depree and Savage, 2001).

The prepared mayonnaise was divided into two portions. The first one was pasteurized at $70^{\circ} \mathrm{C}$ for $15 \mathrm{~min}$. and then cooled. The second portion was left without treatment (unpasteurized). Both portions were transferred to sterile screw capped glass jars under aseptic conditions and stored at $4^{\circ} \mathrm{C}$ for 20 weeks. Samples for each treatment were taken at specified time intervals throughout the storage for chemical, microbiological and sensory evaluations.

\subsection{Chemical analysis}

Moisture, crude protein, total lipids, ash and acid value $(\mathrm{AV})$ were determined in the mayonnaise according to the method described in AOAC (2000). Three replicates were used in each test. The carbohydrate content was calculated by differences. Titratable acidity (T.A) was determined by titrations of $10 \mathrm{~g}$ mayonnaise to $\mathrm{pH} 8.1$ with $0.1 \mathrm{~N} \mathrm{NaOH}$ and results were converted to percentage of acetic acid according to the method of AOAC (2000). The pH values of mayonnaise samples were measured using a pH meter (model CyberScan 500) according to the procedure of (Zaika et al., 1976), using $10 \%$ dispersion of mayonnaise in distilled water. The thiobarbituric acid (TBA) number was determined as described by (Okayama, 1987). Mineral contents, i.e. calcium $(\mathrm{Ca})$, phosphorus $(\mathrm{P})$, iron $(\mathrm{Fe})$, potassium $(\mathrm{K})$, sodium $(\mathrm{Na})$ and zinc $(\mathrm{Zn})$ were determined according to the method of AOAC (2000) using an atomic absorption spectrophotometer Perkin-Elmer 2380.

\subsection{Microbiological analysis}

Total bacterial counts (TBC), yeast, mold counts, $E$. coli, Staphylococcus aureus ( $S$. aureus) and Salmonella spp. were determined according to (APHA, 1992).

\subsection{Sensory evaluation}

A sensory evaluation of mayonnaise samples was conducted after preparation and during storage at $4^{\circ} \mathrm{C}$ for 20 weeks. Sensory characteristics: taste, flavor, color, appearance and overall acceptability were evaluated by a 25-member panel on 10-point hedonic scale, with 1 being the lowest and 10 the highest according to (Ranganna, 1977).

\subsection{Statistical analysis}

Data were subjected to statistical analysis using computerized analysis of variance and Duncan's multiple range test procedures (SAS, 1998). All values are the mean of three replicate analyses.

\section{RESULTS AND DISCUSSION}

The current results in Table 1 clearly indicate that protein and total carbohydrates were found to be lower in ostrich eggs compared to chicken eggs based on dry weight. Whereas ash was found to be higher in ostrich eggs compared to chicken eggs based on dry weight. On the other hand, no 
Table 1

Chemical composition of ostrich eggs compared to chicken eggs (Mean $\pm \mathrm{SE}$ ). (on dry weight basis).

\begin{tabular}{ccc}
\hline Components (\%) & Ostrich eggs & Chicken eggs \\
\hline Protein & $47.09^{\mathrm{a}}$ & $47.14^{\mathrm{a}}$ \\
& \pm & \pm \\
& 0.02 & 0.02 \\
\hline Total lipids & $45.10^{\mathrm{a}}$ & $45.13^{\mathrm{a}}$ \\
& \pm & \pm \\
& 0.01 & 0.01 \\
\hline Ash & $3.79^{\mathrm{a}}$ & $3.10^{\mathrm{b}}$ \\
& \pm & \pm \\
& 0.01 & 0.01 \\
\hline & $4.03^{\mathrm{b}}$ & $4.71^{\mathrm{a}}$ \\
Total carbohydrates & \pm & \pm \\
& 0.01 & 0.01 \\
\hline
\end{tabular}

Within each row, means superscript with different letters are significantly different $(P<0.05)$.

Values are means of three replicates.

* Calculated by differences.

significant differences were found in total lipids in ostrich eggs or chicken eggs.

These findings are in agreement with (Makhlouf et al., 1996) who reported that the contents of protein, total lipids, ash and total carbohydrates in chicken eggs were 46.68, 44.99, 3.02 and 5.31\% based on dry weight, respectively. Moreover, the content of protein and total lipids in pasteurized eggs were 47.3 and $45.2 \%$ based on dry weight, respectively (Caboni et al., 2005). (Likewise, Di Meo et al., 2003) showed that the protein and fat contents in ostrich eggs ranged from 47.7 to $48.2 \%$ based on dry weight and 43.8 to $44.2 \%$ based on dry weight, respectively. However, these authors found a higher ash content 5.2 to $5.5 \%$ based on dry weight compared to the ash content reported in the current study $3.79 \%$ based on dry weight.

Data in Table 2 indicates that the potassium, sodium and zinc were found to be lower in ostrich eggs compared to chicken eggs based on dry weight. Whereas, calcium and iron were found to be higher in ostrich eggs compared to chicken eggs based on dry weight. On the other hand, no significant differences were found in phosphorus and iron in both ostrich and chicken eggs.

The results of the mineral contents reported in the present study are in agreement with (Makhlouf et al., 1996) who reported that the mineral contents of $\mathrm{Ca}, \mathrm{P}, \mathrm{Fe}, \mathrm{K}, \mathrm{Na}$ and $\mathrm{Zn}$ in chicken eggs were 192.45, 720.75, 9.85, 539.62, 407.55 and $5.41 \mathrm{mg} /$ $100 \mathrm{~g}$ based on dry weight, respectively. On the other hand, (Sungino et al., 1997) found that the total mineral content in egg yolk; egg white and egg shell were $0.3,0.2$ and $5.9 \mathrm{mg} / 100 \mathrm{~g}$ based on dry weight, respectively. In addition, the composition of an egg (excluding the shell) - based on a 59 gram shell egg was reported by (Agriculture and AgriFood Canada 1999). The results obtained in this
Table 2

Mineral contents (mg/100 dry weight) of ostrich eggs comparedto chicken eggs (Mean \pm SE).

\begin{tabular}{|c|c|c|}
\hline Minerals & Ostrich eggs & Chicken eggs \\
\hline Calcium & $\begin{array}{c}206.5^{\mathrm{a}} \\
\pm \\
0.15\end{array}$ & $\begin{array}{c}178.0^{b} \\
\pm \\
0.11\end{array}$ \\
\hline Phosphorus & $\begin{array}{c}683.8^{a} \\
\pm \\
0.17\end{array}$ & $\begin{array}{c}672.2^{b} \\
\pm \\
0.17\end{array}$ \\
\hline Iron & $\begin{array}{c}11.20^{\mathrm{a}} \\
\pm \\
0.02\end{array}$ & $\begin{array}{c}9.80^{b} \\
\pm \\
0.02\end{array}$ \\
\hline Potassium & $\begin{array}{c}460.9^{b} \\
\pm \\
0.17\end{array}$ & $\begin{array}{c}498.4^{a} \\
\pm \\
0.23\end{array}$ \\
\hline Sodium & $\begin{array}{c}408.7^{b} \\
\pm \\
0.17\end{array}$ & $\begin{array}{c}415.7^{a} \\
\pm \\
0.17\end{array}$ \\
\hline Zinc & $\begin{array}{c}5.20^{b} \\
\pm \\
0.01\end{array}$ & $\begin{array}{c}6.30^{\mathrm{a}} \\
\pm \\
0.02\end{array}$ \\
\hline
\end{tabular}

Within each row, means superscript with different letters are significantly different $(P<0.05)$.

Values are means of three replicates.

study indicate that $(\mathrm{Ca}+\mathrm{P}),(\mathrm{Mg}+\mathrm{Fe})$ and (iodine $+\mathrm{K}+$ chlorine $+\mathrm{Cu}+\mathrm{Mn}+\mathrm{Na}+$ sulfur + zinc) were 114, 5.72 and $235.663 \mathrm{mg} / 100 \mathrm{~g}$ based on dry weight, respectively.

Mayonnaise, like all high fat foods, is susceptible to spoilage due to auto-oxidation; its stability depends on the type of oil used. Salt, as well as vinegar and mustard are important in the development of the flavor and stability and appear to influence the rate of oxidation of the oil in the emulsion (Depree and Savage, 2001). Generally, mayonnaise stability is dependent on several factors such as amount of oil, amount of egg yolk, viscosity, and relative volume of oil phase to aqueous phase, method of mixing, water quality, and temperature (Harrison and Cunningham, 1985). The quality of unpasteurized and pasteurized mayonnaise manufactured from ostrich eggs in comparison to chicken eggs was evaluated chemically and microbiologically and the obtained data are found in Tables (3 to 6).

The data presented in Table (3) shows that the titratable acidity of unpasteurized mayonnaise made from ostrich eggs increased significantly as the storage period increased up to 20 weeks, compared with the pasteurized one, which showed insignificant changes during storage. On the other hand, the $\mathrm{pH}$ of pasteurized mayonnaise made from ostrich eggs was stable up to 15 weeks, compared with the unpasteurized one which decreased significantly after 10 weeks of storage. However, in mayonnaise from chicken eggs, neither T.A nor Ph 
Table 3

Titratable acidity and $\mathrm{pH}$ (Mean \pm SE). of unpasteurized and pasteurized mayonnaise from ostrich and chicken eggs during storage at $4^{\circ} \mathrm{C}$.

\begin{tabular}{|c|c|c|c|c|c|c|c|c|}
\hline \multirow{3}{*}{$\begin{array}{l}\text { Storage } \\
\text { periods } \\
\text { (week) }\end{array}$} & \multicolumn{4}{|c|}{ Mayonnaise from ostrich eggs } & \multicolumn{4}{|c|}{ Mayonnaise from chicken eggs } \\
\hline & \multicolumn{2}{|c|}{ Unpasteurized } & \multicolumn{2}{|c|}{ Pasteurized } & \multicolumn{2}{|c|}{ Unpasteurized } & \multicolumn{2}{|c|}{ Pasteurized } \\
\hline & T.A \% & PH & T.A \% & PH & T.A \% & PH & T.A \% & PH \\
\hline 0 & 0.239 & $\begin{array}{c}3.59^{a} \\
\pm \\
0.01\end{array}$ & 0.239 & $\begin{array}{c}3.59^{\mathrm{a}} \\
\pm \\
0.01\end{array}$ & 0.238 & $\begin{array}{c}3.63^{a} \\
\pm \\
0.01\end{array}$ & 0.238 & $\begin{array}{c}3.63^{\mathrm{a}} \\
\pm \\
0.01\end{array}$ \\
\hline 5 & 0.241 & $\begin{array}{c}3.59^{a} \\
\pm \\
0.01\end{array}$ & 0.239 & $\begin{array}{c}3.59^{\mathrm{a}} \\
\pm \\
0.01\end{array}$ & 0.239 & $\begin{array}{c}3.62^{\mathrm{a}} \\
\pm \\
0.01\end{array}$ & 0.240 & $\begin{array}{c}3.62^{\mathrm{a}} \\
\pm \\
0.01\end{array}$ \\
\hline 10 & 0.243 & $\begin{array}{c}3.58^{a} \\
\pm \\
0.01\end{array}$ & 0.240 & $\begin{array}{c}3.59^{\mathrm{a}} \\
\pm \\
0.01\end{array}$ & 0.241 & $\begin{array}{c}3.60^{\mathrm{a}} \\
\pm \\
0.01\end{array}$ & 0.241 & $\begin{array}{c}3.60^{\mathrm{a}} \\
\pm \\
0.01\end{array}$ \\
\hline 15 & 0.245 & $\begin{array}{c}3.52^{b} \\
\pm \\
0.01\end{array}$ & 0.241 & $\begin{array}{c}3.55^{\mathrm{ab}} \\
\pm \\
0.01\end{array}$ & 0.241 & $\begin{array}{c}3.60^{\mathrm{a}} \\
\pm \\
0.01\end{array}$ & 0.241 & $\begin{array}{c}3.60^{\mathrm{a}} \\
\pm \\
0.01\end{array}$ \\
\hline 20 & 0.246 & $\begin{array}{c}3.51^{b} \\
\pm \\
0.01\end{array}$ & 0.242 & $\begin{array}{c}3.53^{b} \\
\pm \\
0.01\end{array}$ & 0.242 & $\begin{array}{c}3.59^{\mathrm{a}} \\
\pm \\
0.01\end{array}$ & 0.242 & $\begin{array}{c}3.59^{\mathrm{a}} \\
\pm \\
0.01\end{array}$ \\
\hline
\end{tabular}

Within each column, means superscript with different letters are significantly different $(P<0.05)$.

T.A: Titratable acidity.

Values are means of three replicates.

were significantly steady in pasteurized or unpasteurized mayonnaise during storage. Data revealed that, at the end of storage (20 weeks), the T.A increased by 2.9 and $1.3 \%$ in unpasteurized and pasteurized mayonnaise made from ostrich eggs, respectively.

The growth of lactic acid bacteria led to an increases in acidity and consequently a decrease in $\mathrm{pH}$ values during storage (Worrasinchai et al., 2006), although the percentage of increasing acidity in this investigation was lower than that recorded by (Stefanow, 1989) who reported that the acidity increased from 7 to $8 \%$ after 20 days storage at temperature between -2 and $-5^{\circ} \mathrm{C}$ and $4 \%$ during storage at temperatures between 4 and $10^{\circ} \mathrm{C}$. The $\mathrm{pH}$ of mayonnaise can have a dramatic effect on the structure of the emulsion. According to (Depree and Savage, 2001), the viscoelasticity and stability of the mayonnaise should be at its highest when the $\mathrm{pH}$ is close to the average isoelectric point of the egg yolk proteins and hence the charge on the proteins is minimized. If the proteins on the surface of the droplets were highly charged, this would prevent any further protein from absorbing and also cause the droplets to repel one another, which would prevent flocculation. Both of these factors tend to lead to an emulsion with lower viscosity and lower stability. Moreover, (Kiosseoglou and Sherman, 1983) found that the viscoelasticity of their mayonnaise was highest at a $\mathrm{pH}$ of 3.9 .

The acid values significantly $(P<0.01)$ increased with storage periods in either unpasteurized or pasteurized mayonnaise manufactured from ostrich or chicken eggs as compared to fresh mayonnaise (Table 4). This increase was significantly $(P<0.05)$ inferior in pasteurized mayonnaise compared with unpasteurized samples manufactured either from ostrich or chicken eggs at every period of storage. The data under investigation indicated that the acid values of mayonnaise manufactured from ostrich eggs were lower than that recorded with mayonnaise from chicken eggs. This means that the acid values in pasteurized mayonnaise from both ostrich and chicken eggs were lower than that observed with unpasteurized samples. After 20 weeks of storage, the acid values were 0.50 and 0.78 in unpasteurized mayonnaise from ostrich eggs and chicken eggs, respectively. The corresponding values of pasteurized mayonnaise were 0.47 and 0.59 . The increase in acid values in different mayonnaise samples was probably due to the activity of hydrolytic and oxidative enzymes present in eggs. (Stefanow, 1989). According to (Kishk, 1997), free fatty acids may be produced by the oxidation of double bonds of unsaturated fatty acid esters. In advanced stages of oxidation, free fatty acids with low molecular weight were developed through the accumulation of acidic cleavage products and subsequently increased the acid value. This oxidation could have occurred with the aid of oxidative enzymes and the presence of a proportion of atmospheric oxygen in the headspace and incorporated into the mayonnaise.

As is the case with all fat-containing foods, mayonnaise is susceptible to spoilage through the auto-oxidation of unsaturated and polyunsaturated 
Table 4

Acid value and TBA number (Mean \pm SE) of unpasteurized and pasteurized mayonnaise from ostrich and chicken eggs during storage at $4^{\circ} \mathrm{C}$.

\begin{tabular}{|c|c|c|c|c|c|c|c|c|}
\hline \multirow{3}{*}{$\begin{array}{l}\text { Storage } \\
\text { periods } \\
\text { (week) }\end{array}$} & \multicolumn{4}{|c|}{ Mayonnaise from ostrich eggs } & \multicolumn{4}{|c|}{ Mayonnaise from chicken eggs } \\
\hline & \multicolumn{2}{|c|}{ Unpasteurized } & \multicolumn{2}{|c|}{ Pasteurized } & \multicolumn{2}{|c|}{ Unpasteurized } & \multicolumn{2}{|c|}{ Pasteurized } \\
\hline & AV & TBA & AV & TBA & AV & TBA & AV & TBA \\
\hline 0 & $\begin{array}{c}0.27^{g} \\
\pm \\
0.01\end{array}$ & $\begin{array}{c}0.15^{\mathrm{h}} \\
\pm \\
0.01\end{array}$ & $\begin{array}{c}0.27^{g} \\
\pm \\
0.01\end{array}$ & $\begin{array}{c}0.15^{\mathrm{h}} \\
\pm \\
0.01\end{array}$ & $\begin{array}{c}0.30^{\mathrm{e}} \\
\pm \\
0.01\end{array}$ & $\begin{array}{c}0.18^{h} \\
\pm \\
0.01\end{array}$ & $\begin{array}{c}0.30^{\mathrm{e}} \\
\pm \\
0.01\end{array}$ & $\begin{array}{c}0.18^{h} \\
\pm \\
0.01\end{array}$ \\
\hline 5 & $\begin{array}{c}0.32^{\text {ef }} \\
\pm \\
0.01\end{array}$ & $\begin{array}{c}0.19^{9} \\
\pm \\
0.01\end{array}$ & $\begin{array}{c}0.31^{f} \\
\pm \\
0.00\end{array}$ & $\begin{array}{c}0.19^{g} \\
\pm \\
0.01\end{array}$ & $\begin{array}{c}0.38^{d} \\
\pm \\
0.01\end{array}$ & $\begin{array}{c}0.27^{f} \\
\pm \\
0.01\end{array}$ & $\begin{array}{c}0.36^{d} \\
\pm \\
0.01\end{array}$ & $\begin{array}{c}0.22^{9} \\
\pm \\
0.01\end{array}$ \\
\hline 10 & $\begin{array}{c}0.37^{\text {cd }} \\
\pm \\
0.01\end{array}$ & $\begin{array}{c}0.30^{\mathrm{e}} \\
\pm \\
0.01\end{array}$ & $\begin{array}{c}0.35^{\text {ed }} \\
\pm \\
0.01\end{array}$ & $\begin{array}{c}0.23^{f} \\
\pm \\
0.01\end{array}$ & $\begin{array}{c}0.47^{c} \\
\pm \\
0.01\end{array}$ & $\begin{array}{c}0.41^{d} \\
\pm \\
0.02\end{array}$ & $\begin{array}{c}0.40^{d} \\
\pm \\
0.01\end{array}$ & $\begin{array}{c}0.34^{\mathrm{e}} \\
\pm \\
0.01\end{array}$ \\
\hline 15 & $\begin{array}{c}0.44^{b} \\
\pm \\
0.01\end{array}$ & $\begin{array}{c}0.40^{c} \\
\pm \\
0.01\end{array}$ & $\begin{array}{c}0.39^{c} \\
\pm \\
0.01\end{array}$ & $\begin{array}{c}0.35^{d} \\
\pm \\
0.01\end{array}$ & $\begin{array}{c}0.61^{b} \\
\pm \\
0.02\end{array}$ & $\begin{array}{c}0.49^{c} \\
\pm \\
0.02\end{array}$ & $\begin{array}{c}0.49^{c} \\
\pm \\
0.01\end{array}$ & $\begin{array}{c}0.43^{\mathrm{d}} \\
\pm \\
0.01\end{array}$ \\
\hline 20 & $\begin{array}{c}0.50^{\mathrm{a}} \\
\pm \\
0.01\end{array}$ & $\begin{array}{c}0.56^{\mathrm{a}} \\
\pm \\
0.01\end{array}$ & $\begin{array}{c}0.47^{b} \\
\pm \\
0.01\end{array}$ & $\begin{array}{c}0.49^{b} \\
\pm \\
0.01\end{array}$ & $\begin{array}{c}0.78^{a} \\
\pm \\
0.01\end{array}$ & $\begin{array}{c}0.65^{\mathrm{a}} \\
\pm \\
0.02\end{array}$ & $\begin{array}{c}0.59^{b} \\
\pm \\
0.02\end{array}$ & $\begin{array}{c}0.60^{b} \\
\pm \\
0.01\end{array}$ \\
\hline
\end{tabular}

Within each row, means superscript with different letters are significantly different $(\mathrm{P}<0.05)$.

AV: Acid value.

TBA: Thiobarbituric acid.

Values are means of three replicates.

fats in the oil. Lipid oxidation was measured using TBA numbers during the storage period of different samples and data is presented in Table (4). TBA of unpasteurized and pasteurized mayonnaise manufactured either from ostrich or chicken eggs were significantly $(P<0.01)$ increased as storage period increased, compared with fresh mayonnaise samples (Table 4). The numbers of TBA after 20 weeks were 0.56 and 0.65 (mg malonaldehyde/kg) in unpasteurized mayonnaise made from ostrich eggs and chicken eggs, respectively. A significant $(P<0.05)$ decrease in TBA was detected at every storage period due to pasteurization compared with unpasteurized mayonnaise manufactured either from ostrich or chicken eggs. TBA in pasteurized mayonnaise made from ostrich eggs was 0.49 $\mathrm{mg} / \mathrm{kg}$ and from chicken eggs was $0.60 \mathrm{mg} / \mathrm{kg}$ after storage for 20 weeks. Results also indicated that mayonnaise from ostrich eggs contained a lower TBA value than that detected in mayonnaise made from chicken eggs. The TBA test determines the amount of malonaldehyde, a major secondary byproduct of lipid oxidation in a sample (Botsoglou et al., 1994).

The quality of mayonnaise manufactured from ostrich and chicken eggs with or without pasteurization was evaluated microbiologically (Tables 5 and 6). The current results reveal that mayonnaise made from both ostrich and chicken eggs was found to be free from bacteria after the first week of storage. By week 5 of storage the mayonnaise made from chicken eggs was found to contain a low bacterial count. This may be due to its low $\mathrm{pH}$ and high fat content, mayonnaise is relatively resistant to microbial spoilage, although, the growth of bacteria may occur in mayonnaise ingredients. The data presented in Table 5 also indicates that mayonnaise made from ostrich eggs with or without pasteurization contained lower total bacterial counts than those detected in mayonnaise made from chicken eggs. It was also noticed that pasteurization reduced the growth rate of bacteria in both mayonnaise types (from ostrich or chicken eggs). The current results reveal that the bacterial count of both mayonnaises increased after 20 week of storage; unpasteurized mayonnaise made from ostrich or chicken eggs contained $3.6 \times 10^{4}$ and $4.4 \times 10^{4}$ c.f.u. The corresponding values of pasteurized mayonnaise were $2.6 \times 10^{4}$ and $3.3 \times 10^{4}$, respectively. The increase in total bacterial count at the end of the storage period (e.g. 20 weeks) reported in the current study may be due to the growth of acid tolerant microorganisms such as lactic acid bacteria (Karas et al., 2002). On the contrary, (Worrasinchai et al., 2006) reported that after 64 days storage, the total bacterial count of mayonnaise samples decreased.

Data presented in Table 6 indicates that molds and yeasts were not detected in the different mayonnaise samples during the first 5 weeks. However, they occurred later on and their growth rate increased during the storage period. The maximum counts were observed at 20 weeks. The growth rate of pasteurized mayonnaise was lower than that recorded in unpasteurized mayonnaise. On the other hand, mayonnaise made from ostrich 
eggs was less contaminated than the one made from chicken eggs. After 20 weeks of storage the counts of molds and yeast were $1.1 \times 10^{2}$ and $2.1 \times$ $10^{2}$ in pasteurized mayonnaise made from ostrich and chicken eggs, respectively. The corresponding values in unpasteurized mayonnaise were $1.7 \times 10^{2}$ and $2.9 \times 10^{2}$
From a microbiological safety point of view, it is generally recommended that mayonnaise made with unpasteurized eggs is prepared with vinegar to a $\mathrm{pH}$ of 4.1 or less and stored at room temperature $\left(18-22^{\circ} \mathrm{C}\right)$ for at least $24 \mathrm{~h}$ to reduce the risk from microorganisms (Radford and Board, 1993). They also added that the addition of mustard and salt to

Table 5

Total bacterial counts (Mean $\pm \mathrm{SE}$ ) of unpasteurized and pasteurized mayonnaise from ostrich and chicken eggs during storage at $4^{\circ} \mathrm{C}$.

\begin{tabular}{|c|c|c|c|c|}
\hline \multirow{3}{*}{$\begin{array}{l}\text { Storage } \\
\text { periods } \\
\text { (week) }\end{array}$} & \multicolumn{4}{|c|}{ Total bacterial counts (c.f.u/g) } \\
\hline & \multicolumn{2}{|c|}{ Mayonnaise from ostrich eggs } & \multicolumn{2}{|c|}{ Mayonnaise from chicken eggs } \\
\hline & Unpasteurized & Pasteurized & Unpasteurized & Pasteurized \\
\hline \multirow[b]{2}{*}{0} & $7.4^{\mathrm{b}}$ & $5.4^{\mathrm{b}}$ & $8.3^{\mathrm{a}}$ & $6.4^{\mathrm{a}}$ \\
\hline & $0 \stackrel{ \pm}{05}$ & $0 \pm$ & $\stackrel{ \pm}{0.99}$ & \pm \pm 14 \\
\hline \multirow{3}{*}{5} & $7.7^{b}$ & $5.4^{b}$ & $8.6^{\mathrm{a}}$ & $66^{a}$ \\
\hline & \pm & $\begin{array}{c}0.7 \\
\pm\end{array}$ & \pm & \pm \\
\hline & 0.14 & 0.17 & 0.14 & 0.14 \\
\hline \multirow{3}{*}{10} & $8.7^{b}$ & $6.4^{\mathrm{b}}$ & $9.4^{\mathrm{a}}$ & $7.7^{\mathrm{a}}$ \\
\hline & \pm & \pm & \pm & \pm \\
\hline & 0.12 & 0.14 & 0.17 & 0.14 \\
\hline \multirow{3}{*}{15} & $7.5^{\mathrm{a}}$ & $3.2^{b}$ & $6.9^{b}$ & $4.3^{\mathrm{a}}$ \\
\hline & \pm & \pm & \pm & \pm \\
\hline & 0.11 & 0.14 & 0.14 & 0.14 \\
\hline \multirow{3}{*}{20} & $3.6^{\mathrm{b}}$ & $2.6^{b}$ & $4.4^{\mathrm{a}}$ & $3.3^{a}$ \\
\hline & \pm & \pm & \pm & \pm \\
\hline & 0.14 & 0.11 & 0.11 & 0.11 \\
\hline
\end{tabular}

Within each row, means superscript with different letters are significantly different $(P<0.05)$.

Values are means of three replicates.

* Fresh $\left(x 10^{2}\right), 5$ week $\left(x 10^{2}\right), 10$ week $\left(x 10^{2}\right), 15$ week $\left(x 10^{3}\right), 20$ week $\left(x 10^{4}\right)$.

Table 6

Mold and yeast counts (Mean \pm SE) of unpasteurized and pasteurized mayonnaise from ostrich and chicken eggs during storage at $4^{\circ} \mathrm{C}$.

\begin{tabular}{|c|c|c|c|c|}
\hline \multirow{3}{*}{$\begin{array}{c}\text { Storage } \\
\text { periods } \\
\text { (week) }\end{array}$} & \multicolumn{4}{|c|}{ Mold and yeast counts (c.f.u/gm) } \\
\hline & \multicolumn{2}{|c|}{ Mayonnaise from ostrich eggs } & \multicolumn{2}{|c|}{ Mayonnaise from chicken eggs } \\
\hline & Unpasteurized & Pasteurized & Unpasteurized & Pasteurized \\
\hline 0 & - & - & - & - \\
\hline 5 & - & - & 1.0 & - \\
\hline 10 & $\begin{array}{c}1.0^{\mathrm{a}} \\
\pm \\
0.03\end{array}$ & - & $\begin{array}{c}1.1^{\mathrm{a}} \\
\pm \\
0.05\end{array}$ & 1.1 \\
\hline 15 & $\begin{array}{c}1.5^{\mathrm{b}} \\
\pm \\
0.05\end{array}$ & $\begin{array}{c}1.8^{\mathrm{a}} \\
\pm \\
0.05\end{array}$ & $\begin{array}{c}2.2^{a} \\
\pm \\
0.08\end{array}$ & $\begin{array}{c}1.7^{b} \\
\pm \\
0.05\end{array}$ \\
\hline 20 & $\begin{array}{c}1.7^{b} \\
\pm \\
0.11\end{array}$ & $\begin{array}{c}1.1^{\mathrm{b}} \\
\pm \\
0.05\end{array}$ & $\begin{array}{c}2.9^{a} \\
\pm \\
0.03\end{array}$ & $\begin{array}{c}2.1^{\mathrm{a}} \\
\pm \\
0.11\end{array}$ \\
\hline
\end{tabular}

Within each row, means superscript with different letters are significantly different $(P<0.05)$.

Values are means of three replicates.

* 10 week $\left(x 10^{2}\right), 15$ week $\left(\times 10^{2}\right), 20$ week $\left(\times 10^{2}\right)$. 
Table 7

Sensory properties (Mean \pm SD) of unpasteurized and pasteurized mayonnaise manufactured from ostrich and chicken eggs during storage at $4^{\circ} \mathrm{C}$.

\begin{tabular}{|c|c|c|c|c|c|c|c|}
\hline \multirow{3}{*}{$\begin{array}{c}\text { Sensory } \\
\text { properties }\end{array}$} & & \multicolumn{6}{|c|}{ Storage periods at $4{ }^{\circ} \mathrm{C}$} \\
\hline & & \multicolumn{2}{|c|}{ 0. time } & \multicolumn{2}{|c|}{10 weeks } & \multicolumn{2}{|c|}{20 weeks } \\
\hline & & A & B & A & B & A & B \\
\hline \multirow{2}{*}{ Taste } & 1 & $\begin{array}{c}9.0^{a} \\
\pm \\
0.0\end{array}$ & $\begin{array}{c}9.0^{\mathrm{a}} \\
\pm \\
0.11\end{array}$ & $\begin{array}{c}8.8^{\mathrm{ab}} \\
\pm \\
0.11\end{array}$ & $\begin{array}{c}8.8^{a b} \\
\pm \\
0.17\end{array}$ & $\begin{array}{c}8.5^{b} \\
\pm \\
0.17\end{array}$ & $\begin{array}{c}8.5^{b} \\
\pm \\
0.11\end{array}$ \\
\hline & 2 & $\begin{array}{c}9.0^{\mathrm{a}} \\
\pm \\
0.11\end{array}$ & $\begin{array}{c}9.0^{\mathrm{a}} \\
\pm \\
0.11\end{array}$ & $\begin{array}{c}9.0^{\mathrm{a}} \\
\pm \\
0.11\end{array}$ & $\begin{array}{c}8.5^{b} \\
\pm \\
0.11\end{array}$ & $\begin{array}{c}8.0^{\circ} \\
\pm \\
0.11\end{array}$ & $\begin{array}{c}8.2^{b c} \\
\pm \\
0.11\end{array}$ \\
\hline \multirow{2}{*}{ Flavor } & 1 & $\begin{array}{c}9.0^{a} \\
\pm \\
0.14\end{array}$ & $\begin{array}{c}9.0^{\mathrm{a}} \\
\pm \\
0.11\end{array}$ & $\begin{array}{c}8.8^{\mathrm{a}} \\
\pm \\
0.17\end{array}$ & $\begin{array}{c}9.0^{\mathrm{a}} \\
\pm \\
0.11\end{array}$ & $\begin{array}{c}8.2^{b} \\
\pm \\
0.11\end{array}$ & $\begin{array}{c}8.8^{a} \\
\pm \\
0.17\end{array}$ \\
\hline & 2 & $\begin{array}{c}9.0^{\mathrm{a}} \\
\pm \\
0.11\end{array}$ & $\begin{array}{c}9.0^{\mathrm{a}} \\
\pm \\
0.11\end{array}$ & $\begin{array}{c}8.5^{b c} \\
\pm \\
0.11\end{array}$ & $\begin{array}{c}8.6^{b} \\
\pm \\
0.08\end{array}$ & $\begin{array}{c}8.2^{c} \\
\pm \\
0.11\end{array}$ & $\begin{array}{c}8.4^{b c} \\
\pm \\
0.11\end{array}$ \\
\hline \multirow{2}{*}{ Color } & 1 & $\begin{array}{c}9.5^{\mathrm{a}} \\
\pm \\
0.11\end{array}$ & $\begin{array}{c}9.5^{\mathrm{a}} \\
\pm \\
0.11\end{array}$ & $\begin{array}{c}8.8^{b} \\
\pm \\
0.17\end{array}$ & $\begin{array}{c}9.0^{b} \\
\pm \\
0.11\end{array}$ & $\begin{array}{c}8.3^{c} \\
\pm \\
0.11\end{array}$ & $\begin{array}{c}8.8^{b} \\
\pm \\
0.17\end{array}$ \\
\hline & 2 & $\begin{array}{c}9.5^{\mathrm{a}} \\
\pm \\
0.11\end{array}$ & $\begin{array}{c}9.5^{\mathrm{a}} \\
\pm \\
0.11\end{array}$ & $\begin{array}{c}8.8^{b} \\
\pm \\
0.17\end{array}$ & $\begin{array}{c}9.0^{b} \\
\pm \\
0.05\end{array}$ & $\begin{array}{c}8.1^{c} \\
\pm \\
0.05\end{array}$ & $\begin{array}{c}8.6^{b} \\
\pm \\
0.17\end{array}$ \\
\hline \multirow{2}{*}{ Appearance } & 1 & $\begin{array}{c}9.5^{\mathrm{a}} \\
\pm \\
0.11\end{array}$ & $\begin{array}{c}9.5^{\mathrm{a}} \\
\pm \\
0.11\end{array}$ & $\begin{array}{c}8.8^{b c} \\
\pm \\
0.17\end{array}$ & $\begin{array}{c}9.0^{b} \\
\pm \\
0.08\end{array}$ & $\begin{array}{c}8.1^{d} \\
\pm \\
0.05\end{array}$ & $\begin{array}{c}8.5^{c} \\
\pm \\
0.12\end{array}$ \\
\hline & 2 & $\begin{array}{c}9.5^{\mathrm{a}} \\
\pm \\
0.11\end{array}$ & $\begin{array}{c}9.5^{\mathrm{a}} \\
\pm \\
0.11\end{array}$ & $\begin{array}{c}8.6^{c} \\
\pm \\
0.17\end{array}$ & $\begin{array}{c}9.0^{b} \\
\pm \\
0.11\end{array}$ & $\begin{array}{c}8.0^{d} \\
\pm \\
0.11\end{array}$ & $\begin{array}{c}8.3^{\text {cd }} \\
\pm \\
0.11\end{array}$ \\
\hline \multirow{2}{*}{$\begin{array}{l}\text { Overall } \\
\text { Acceptability }\end{array}$} & 1 & $\begin{array}{c}9.3^{\mathrm{a}} \\
\pm \\
0.17\end{array}$ & $\begin{array}{c}9.3^{\mathrm{a}} \\
\pm \\
0.17\end{array}$ & $\begin{array}{c}8.7^{b} \\
\pm \\
0.11 \\
\end{array}$ & $\begin{array}{c}9.0^{\mathrm{ab}} \\
\pm \\
0.11\end{array}$ & $\begin{array}{c}8.2^{c} \\
\pm \\
0.11\end{array}$ & $\begin{array}{c}8.7^{b} \\
\pm \\
0.11\end{array}$ \\
\hline & 2 & $\begin{array}{c}9.3^{\mathrm{a}} \\
\pm \\
0.17\end{array}$ & $\begin{array}{c}9.3^{\mathrm{a}} \\
\pm \\
0.17\end{array}$ & $\begin{array}{c}8.5^{\mathrm{b}} \\
\pm \\
0.11\end{array}$ & $\begin{array}{c}8.8^{b} \\
\pm \\
0.17\end{array}$ & $\begin{array}{c}8.0^{\circ} \\
\pm \\
0.11\end{array}$ & $\begin{array}{c}8.5^{b} \\
\pm \\
0.11\end{array}$ \\
\hline
\end{tabular}

Within each row, means superscript with different letters are significantly different $(P<0.05)$.

Values are means of three replicates.

$\begin{array}{ll}\text { (A) Unpasteurized samples. } & \text { (B) Pasteurized samples. } \\ \text { 1- Mayonnaise from ostrich eggs. } & \text { 2- Mayonnaise from chicken eggs. }\end{array}$

mayonnaise at concentrations of $0.3-1.5 \%(\mathrm{w} / \mathrm{w})$ resulted in an increase in the death rate of Salmonella. The low contamination level of mayonnaise made from ostrich eggs compared to that prepared from chicken eggs may be due to the occurrence of certain elements in ostrich eggs that have antifungal properties (Di Meo et al., 2003).

Sensory analyses were carried out on mayonnaise samples made from ostrich or chicken eggs, with or without pasteurization during the storage period for 20 weeks at $4^{\circ} \mathrm{C}$ (Table 7). The taste and flavor scores of ostrich egg mayonnaise showed significantly $(P<0.05)$ lower values at the end of the storage period ( 20 weeks) with or without pasteurization compared to fresh or after 10 weeks storage (Table 7). The same trend was observed in mayonnaise made from chicken eggs after 10 or 20 week storage periods, compared to fresh. However, the taste scores for the two types of mayonnaise was not significantly affected during the storage periods. These results are in accordance with (Hoffmann 1989 and Kishk 1997). Mayonnaise contained balanced proportions of salt, vinegar and spicing (mustard) that contributed to its taste. Because of the relatively high content of vinegar, a mayonnaise is characterized by a sour taste. Also, the decrease in flavor scores occurring during storage at 
different rates was attributed to the degree of further hydrolysis and development of oxidative changes during storage, which led to several intermediate by products and finally to a series of aldehydes, ketones, alcohols and other compounds that affected flavor (Kishk, 1997).

Regarding color, appearance and the overall acceptability scores of ostrich or chicken egg mayonnaise, both received showed significantly $(P<0.05)$ lower scores after 10 or 20 weeks of storage with or without pasteurization in comparison to fresh ones (Table 7). However, the color, appearance and overall acceptability scores were not significantly affected by the two types of mayonnaise during the storage periods.

Color is one of the most important quality attributes of mayonnaise because color is the one criterion a consumer uses to select a mayonnaise brand from the grocer's shelf. The yellowish color of mayonnaise is primarily provided by egg yolk carotenoids. The oil and mustard used do not contribute a color simulating that provided by egg yolk (Kishk, 1997), The average data in Table 7 indicates that the received color scores of mayonnaise from ostrich eggs and chicken eggs had insignificant values between unpasteurized and pasteurized samples, both being 9.5 before storage. As the storage period increased the color scores slightly and gradually decreased reaching their minimal values of 8.3 and 8.8 for unpasteurized and pasteurized mayonnaise from ostrich eggs, respectively. The corresponding values of chicken egg mayonnaise were 8.1 and 8.6. It was obvious that using either ostrich eggs or chicken eggs in mayonnaise showed an insignificant decrease in color scores during the subsequent storage period for 20 weeks at $4^{\circ} \mathrm{C}$. The decrease in panelists' scores of the mayonnaise samples with prolonged storage period may be due to the reduction in color as a result of the oxidation of certain carotenoids which occurred during storage. This finding is in accordance with those of (Hoffmann 1989 and Kishk (1997).

\section{CONCLUSIONS}

It could be concluded that mayonnaise from ostrich eggs was found to contain high levels of protein, total lipids, carbohydrates, and minerals. It was also found that mayonnaise from ostrich eggs was stable and resistant to microbial spoilage during storage as well as possessing higher sensory and acceptability properties.

\section{REFERENCES}

Agriculture and Agri- Food Canada. 1999. Snapshot of the Canadian egg industry. Annual Report, Canadian Egg Marketing Agency.

Aluko RE, Mine Y. 1997. Competitive adsorption of hen's egg yolk granule lipoproteins and phosvitin in oil-inwater emulsion. J. Agric. Food Chem. 45, 4564-4570.
APHA. 1992. American Public Health Association. Compendium of Methods for the Microbiological Examination of Foods.

A.O.A.C. 2000. Official Methods of Analysis of Association of Official Analytical Chemists International Published by A.O.A.C. International Suit 4002200 Wilson Boulevard Arlington, Virginia 222013301. USA

Brabant LE. 1992. Please squeeze the dressings: new sales opportunities in Japan. AgExporter 4, 12-13.

Botsoglou NA, Fletovris DJ, Papageorgiou, GE, Vassilopoulos VN, Mantis AJ, Trakatellis A. 1994. Rapid, sensitive, and specific thiobarbituric acid method for measuring lipid peroxidation in animal tissue, food, and feedstuff samples J. Agric. Food Chem. 42, 1931 - 1937.

Caboni MF, Boselli E, Messia MC, Velazco A, Fratianni G, Panfili Marconi. E. 2005. Effect of processing and storage on the chemical quality markers of spraydried whole egg. Food Chem. 92, 293-303.

Davis C, Reeves R. 2002. High value opportunities from the chicken egg. A report for the Rural Industries Research and Development Corporation.

Depree JA, Savage G.P. 2001. Physical and flavour stability of mayonnaise. Trends Food Sci. Tech. 12, 157-163.

Di Meo C, Stanco G, Cutrignelli MI, Castaldo S, Nizza A. 2003. Physical and chemical quality of ostrich eggs during the laying season. British Poultry Sci. 44 (3) 386-390.

Harrison LJ, Cunningham FE. 1985. Factors influencing the quality of mayonnaise. J. of Food Qual. 8, 1-20.

Hoffmann G. 1989. The chemistry and technology of edible oils and fats and their high fat products. Academic Press. Inc., Great Britain, Eddmundsbury.

Karas R, Skvarãa M, Îlender B. 2002. Sensory quality of standard and light mayonnaise during storage. Food Tech. Biotech. 40 (2) 119-127.

Kiosseoglou VD, Sherman P. 1983. Colloid Polymer Sci., 261, 520-526. Cited by Aluku, RE, Mine, Y. Characterization of oil-in-water emulsion stability by hen's egg yolk. Granule. Food Hydrocolloids 12 (1998) 203-210.

Kishk YFM. 1997. Role of some vegetable oils in mayonnaise characteristics. M.Sc. Thesis. Faculty of Agric. Ain Shams Univ.

Makhlouf SKM, Fahaeid SMM, El-Faham SY. 1996. Comparative study on utilization of Quail and chicken eggs in cookies manufacture. Egypt. J. Food Sci. 24 (1) $47-59$

Okayama T. 1987. Effect of modified gas atmosphere packaging after deep treatment on myoglobin and lipid oxidation of beef steak. Meat Sci. 19 (3) 179-185.

Palmer HH, ljichi K, Cimino SL, Roff H. 1969. Food Technology 23, 148-156. C.F.Y. Mine.). Emulsifying characterization of hen's egg yolk proteins in oil-in-water emulsions. Food Hydrocolloids 12 (1998) 409-415.

Radford SA, Board RG. 1993. Review: Fate of pathogens in home- made mayonnaise and related products. Food Microbiol 10 (4): 269-278.

Ranganna S. 1977. Manual of analysis of fruits and vegetable products. Tata egraw-Hill Publishing Company Limited New Delhi.

SAS. 1998. SAS/STAT user's Guide Release 6.03 edition. SAS Institute Inc., Cary, Nc, USA.

Stadelman W.J. 1999. The incredibly functional egg. Poultry Sci. 78, 807-811.

Stefanow L. 1989. Changes in mayonnaise quality. Lebensmittel Industrie 36, 207-208. 
Sungino H, Nitoda T, Juneja LR. 1997. General chemical composition of hen eggs. In: Han eggs: Their basic and applied science. Yammamoti T, Juneja LR, Halta $\mathrm{H}$ and Kim M (Eds). CRC Press.

Worrasinchai S, Suphantharika M, Pinjai S, Jamnong P. 2006. B- Glucan prepared from spent brewer's yeast as a fat replacer in mayonnaise. Food Hydrocolloids 20, 68-78.
Zaika LL, Zell TL, Smith ZL, Palumbo SA, Kissinger JC. 1976. The role of nitrite and nitrate in Lebanon Bologna, a fermented sausage. J. Food Sci. 14, 14571460. 